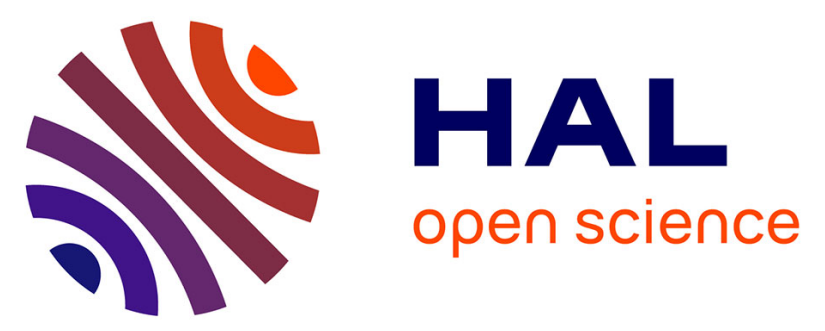

\title{
Efficiency of DMSO as hydroxyl radical probe in an Electrochemical Advanced Oxidation Process - Reactive oxygen species monitoring and impact of the current density
}

Arwa Abou Dalle, Lionel Domergue, Florence Fourcade, Aymen Amin Assadi, Hayet Djelal, Thomas Lendormi, Isabelle Soutrel, Samir Taha, Abdeltif Amrane

\section{- To cite this version:}

Arwa Abou Dalle, Lionel Domergue, Florence Fourcade, Aymen Amin Assadi, Hayet Djelal, et al.. Efficiency of DMSO as hydroxyl radical probe in an Electrochemical Advanced Oxidation Process Reactive oxygen species monitoring and impact of the current density. Electrochimica Acta, 2017, 246, pp.1-8. 10.1016/j.electacta.2017.06.024 . hal-01578540

HAL Id: hal-01578540

https://hal-univ-rennes1.archives-ouvertes.fr/hal-01578540

Submitted on 29 Aug 2017

HAL is a multi-disciplinary open access archive for the deposit and dissemination of scientific research documents, whether they are published or not. The documents may come from teaching and research institutions in France or abroad, or from public or private research centers.
L'archive ouverte pluridisciplinaire HAL, est destinée au dépôt et à la diffusion de documents scientifiques de niveau recherche, publiés ou non, émanant des établissements d'enseignement et de recherche français ou étrangers, des laboratoires publics ou privés. 
Efficiency of DMSO as hydroxyl radical probe in an Electrochemical Advanced Oxidation Process - Reactive oxygen species monitoring and impact of the current density

Arwa ABOU DALLE ${ }^{\mathrm{a}, \mathrm{b}}$, Lionel DOMERGUE ${ }^{\mathrm{a}}$, Florence FOURCADE $^{\mathrm{a}}$, Aymen Amin ASSADI $^{\mathrm{a}}$, Hayet DJELAL ${ }^{\text {a,e }}$, Thomas LENDORMIc ${ }^{\text {, Isabelle SOUTREL }}{ }^{\text {, }}$, Samir TAHA ${ }^{\text {b,d }}$, Abdeltif AMRANE ${ }^{\mathbf{a}}$

a. Ecole Nationale Supérieure de Chimie de Rennes, Université de Rennes 1, UMR-CNRS 6226,11 Allée de Beaulieu, CS 50837, 35708 Rennes cedex 7, France.

b. Laboratoire de Biotechnologies Appliquées, Centre AZM pour la recherche en biotechnologies et ses applications, Ecole doctorale des sciences et technologies, Université Libanaise, Rue Al-Mitein, Tripoli, Liban.

c. Université Bretagne Sud, FRE CNRS 3744, IRDL, F-56300 Pontivy, France

d. Faculté de Santé Publique, Université Libanaise, quartier Dam et Farz, Tripoli, Liban.

e. Ecole des Métiers de l'Environnement, Campus de Ker Lann, 35170 Bruz, France 


\title{
Highlights
}

- Highest hydrogen peroxide concentration and MTZ mineralization obtained for $0.07 \mathrm{~mA} . \mathrm{cm}^{-2}$

- The evolution ${ }^{\circ} \mathrm{OH}$ concentration was not in accordance with that of MTZ mineralization

- Dissolved oxygen can become a limiting reagent for ${ }^{\circ} \mathrm{OH}$ quantification with DMSO

- DMSO can be oxidized and reduced at the electrodes surface distorting ${ }^{\circ} \mathrm{OH}$ quantification

- DMSO efficient as ${ }^{\circ} \mathrm{OH}$ probe until $0.07 \mathrm{~mA} . \mathrm{cm}^{-2}$ in this study, not efficient for electrooxidation

\begin{abstract}
In electro-Fenton process, current density is a key operating parameter for organic compound mineralization. In order to explain mineralization yields obtained during the electrochemical treatment of an antibiotic metronidazole (MTZ) in a mono-compartment batch reactor, the evolution of the reactive oxygen species was discussed. Dissolved oxygen, Hydrogen peroxide and hydroxyl radical $\left({ }^{\circ} \mathrm{OH}\right)$ concentrations were followed during electrolysis performed at current intensities from 50 to $600 \mathrm{~mA}$ corresponding to current densities from 0.04 to $0.45 \mathrm{~mA} . \mathrm{cm}^{-2}$, using a three dimensional graphite felt as working electrode. Dimethylsulfoxide (DMSO) was used to trap hydroxyl radicals by the production of a stable intermediate, methanesulfonate; however the evolution of hydroxyl radical concentration was not in accordance with MTZ mineralization yields. Results showed that on the one hand, for the highest studied current densities, dissolved oxygen could become a limiting reagent for the ${ }^{\circ} \mathrm{OH}$ quantification. On the other hand, DMSO can be oxidized and reduced at the electrodes surface. Indeed, Dimethyl sulfide (DMS), a byproduct from the electrochemical reduction of DMSO was detected during the electrolysis. DMSO appeared therefore relevant as a hydroxyl radical probe in the case of the electro-Fenton process only for low applied current densities, until $0.07 \mathrm{~mA} . \mathrm{cm}^{-2}$ in the present study.
\end{abstract}

Keywords : electro-Fenton; hydroxyl radical probe; Dimethylsulfoxide; current density. 


\section{Introduction}

For more than thirty years, Advanced Oxidation Processes proved their efficiency for the removal of Persistent Organic Pollutants (POP) [1-4]. This class of processes includes some electrochemical ones, which have also proved their relevance for an environmental purpose $[5,6]$. Among them, electro-Fenton is an indirect Electrochemical Advanced Oxidation Process based on the Fenton's reaction (Eq.1):

$\mathrm{Fe}^{2+}+\mathrm{H}_{2} \mathrm{O}_{2} \rightarrow \mathrm{Fe}^{3+}+\mathrm{OH}^{-}+{ }^{\circ} \mathrm{OH}$

In this process, hydrogen peroxide is in-situ produced by the two-electron reduction of dissolved oxygen (Eq.2) and ferrous ions, added in solution in catalytic amount, are regenerated at the cathode surface (Eq.3). The production of hydroxyl radicals in solution allows the oxidation of a wide range of organic compounds.

$\mathrm{O}_{2}+2 \mathrm{e}^{-}+2 \mathrm{H}^{+} \rightarrow \mathrm{H}_{2} \mathrm{O}_{2}$

$\mathrm{Fe}^{3+}+\mathrm{e}^{-} \rightarrow \mathrm{Fe}^{2+}$

According to the literature, the optimal potential for electro-Fenton is $-0.5 \mathrm{~V} / \mathrm{ECS}[2,7]$, but working at controlled potential needs an experimental set-up involving three electrodes (cathode, anode and reference electrode). Because of the brittleness of the reference electrode and the risk of a potential drift for long duration electrolysis, galvanostatic electrolysis are preferred even if working at controlled current intensity is less selective. 
In the electro-Fenton process optimization, the influence of some operating parameters, such as the current intensity or current density, the concentration in ferrous ions, $\mathrm{pH}$, the concentration and the nature of the supporting electrolyte on the process efficiency is studied in order to enhance the production of hydroxyl radicals [2]. It is well known that hydroxyl radical is a strong short-lived oxidant [2]. Their quantification can be effective with techniques such as Electron Paramagnetic Resonance, EPR, in the presence of spin trap agents $[8,9]$. Indirect quantification of hydroxyl radicals can also be implemented using a radical scavenger through its concentration decrease or through the production of a stable intermediate when the stoichiometry of the radical reaction is known. In Advanced Oxidation Processes (AOP), several hydroxyl radical probes have been tested. For instance, phthalhydrazine (Phth) was studied for hydroxyl radical quantification because its hydroxylation leads to the formation of a chemiluminescent stable intermediate: the 5hydroxy-2,3-dihydro-1,4-phthalazinedione (Phth-OH) [9, 10]. Fluorescence can also be applied in the case of coumarin; its reaction with hydroxyl radicals leads to a fluorescent byproduct, the 7-hydroxycoumarin [11-13].

4-hydroxybenzoic acid [14], $\rho$-chlorobenzoic acid [15] and salicylic acid [16, 17] can be used as trapping reagent for ${ }^{\circ} \mathrm{OH}$ radicals' determination due to the hydroxylation of their aromatic ring. Atrazine [18], deethylatrazine [19] have been also studied as hydroxyl radical probe since the degradation of these compounds can be easily followed by HPLC.

In Electrochemical Advanced Oxidation Processes (EAOP), such as electro-Fenton or electrooxidation, the choice of the hydroxyl radical scavenger should also take into account a possible reaction at the electrode surface or a reaction with electro generated species. For example $\rho$-nitrosodimethylaniline, already considered as a possible probe compound due to its high selectivity toward hydroxyl radicals [1], was studied in electrochemical oxidation [20]. It was demonstrated that in $0.05 \mathrm{M} \mathrm{Na}_{2} \mathrm{SO}_{4}$ supporting electrolyte, $\rho$-nitrosodimethylaniline 
could react with lattice active oxygen without hydroxyl radicals being intermediately present. With $\mathrm{NaCl}$ as supporting electrolyte, active chlorine species produced from chloride ions oxidation could react with the considered ${ }^{\circ} \mathrm{OH}$ radical probe leading again to an incorrect quantification of hydroxyl radicals.

Concerning benzene ring compounds, electrochemical polymerization can occur at the anode surface during the electro-oxidation process [21-25]. In an electro-Fenton process performed in a mono-compartment reactor, using such types of compounds as hydroxyl radical probe could produce misleading results.

Dimethylsulfoxide (DMSO) is usually used as solvent in organic electrochemistry [26] and was already studied as hydroxyl radical probe in $\mathrm{UV} / \mathrm{H}_{2} \mathrm{O}_{2}$ and Fenton processes [27-29] and especially in electro-Fenton process [29].

The mechanism of DMSO oxidation by hydroxyl radicals was determined by Lee et al. [28]. Two major pathways can be considered. In fact, DMSO is first oxidized in methanesulfinate and methyl radical; this latter is in turn oxidized to formaldehyde. Regarding methanesulfinate, it reacts very fast with hydroxyl radicals $\left(1.1 \mathrm{mM}^{\mathrm{min}} \mathrm{m}^{-1}\right.$ instead of 0.1 $\mathrm{mM} \cdot \mathrm{min}^{-1}$ for DMSO in the same operating conditions) to produce the stable methanesulfonate intermediate. Indeed, its kinetic constant for the reaction with hydroxyl radicals is around $0.810^{7} \mathrm{M}^{-1} \mathrm{~s}^{-1}$ compared to that of the reaction of methanelsulfinate $\left(5.310^{9}\right.$ $\left.\mathrm{M}^{-1} \mathrm{~s}^{-1}\right)$. Then, following the concentrations of methanesulfonate and formaldehyde during the electrolysis can be a possible way for ${ }^{\circ} \mathrm{OH}$ concentration monitoring during the electrochemical process in a mono-compartment batch reactor.

In this study, on the one hand, reactive oxygen species (dissolved oxygen, hydrogen peroxide and hydroxyl radical) concentrations were followed during electrolysis to better understand 
the influence of the current density on process performance in terms of the metronidazole oxidation and mineralization.

Metronidazole degradation was already studied in the literature. Pérez et al. [30] showed a low mineralization yield for metronidazole (MTZ) by electro-Fenton, in accordance with those obtained by other AOP [31, 32] and mainly due to the presence of heterocyclic byproducts. In this study, mineralization was improved by solar irradiation since the mineralization yield tripled. Indeed mineralization yield increased from $17 \%$ to $53 \%$ with UV irradiation from sunlight for an initial MTZ concentration of $1.39 \mathrm{mM}\left(238 \mathrm{mg} \cdot \mathrm{L}^{-1}\right)$ after 300 min of electrolysis at $55.4 \mathrm{~mA} . \mathrm{cm}^{-2}$ in $0.1 \mathrm{M} \mathrm{Na}_{2} \mathrm{SO}_{4}$ with $0.5 \mathrm{mM}$ of ferrous ions.

To understand the influence of current density, four different ones were tested. The two lowest current densities were close to the electro-Fenton operating conditions. The highest ones were tested to approach electro-oxidation operating conditions on the anode surface. On the other hand, the feasibility of using DMSO as hydroxyl radical probe in an Electrochemical Advanced Oxidation Processes was also discussed.

\section{Materials and methods}

\subsection{Chemicals and materials}

$\mathrm{FeSO}_{4} \cdot 7 \mathrm{H}_{2} \mathrm{O}$ (purity 99\%) and $\mathrm{Na}_{2} \mathrm{SO}_{4}$ (purity 99\%) were obtained from Acros Organics (Thermo Fisher Scientific, Geel, Belgium). Acetonitrile (purity 99.9\%) (HPLC grade) was taken from Sigma-Aldrich (St. Quentin Fallavier, France). MTZ (2-methyl-5-nitroimidazole1-ethanol) with $99 \%$ of purity was also purchased from Sigma-Aldrich. All solutions were prepared with ultrapure water and all the other chemicals used for analysis were purchased from Acros and Sigma. 


\subsection{Electrochemical Apparatus and Procedures}

\subsubsection{Electrochemical treatment to $\mathrm{MTZ}$}

Experiments were performed at ambient temperature $\left(20^{\circ} \mathrm{C}\right)$ with an electrochemical batch monocompartment reactor containing $250 \mathrm{~cm}^{3}$ of solution. The electrochemical cell was monitored by an ammeter power supply (Microsonic systems, Microlab MX 20V-2A, Villette d'Anthon, France). The working electrode (cathode) was a tri-dimensional piece of graphite felt of $42 \mathrm{~cm}^{3}$ (geometrical volume) (Le Carbone Lorraine RVG 4000 Mersen, Paris la Défense, France). It was placed on the inner wall of the cell and the anode was a platinum hollow cylinder $\left(31.2 \mathrm{~cm}^{2}\right)$, centered in the electrochemical reactor and surrounded by the cathode to get a good potential distribution. To reach a stationary $\mathrm{O}_{2}$ concentration, compressed air was bubbled into the solution $\left(0.5 \mathrm{~L} \cdot \mathrm{min}^{-1}\right)$ for $10 \mathrm{~min}$ before and all along the electrolysis. A catalytic quantity of $\mathrm{FeSO}_{4}, 7 \mathrm{H}_{2} \mathrm{O}$ as ferrous ion source was added into the cell just before the beginning of the electrolysis. The ionic strength was maintained constant by the addition of $50 \mathrm{mmol} . \mathrm{L}^{-1} \mathrm{Na}_{2} \mathrm{SO}_{4}$ and the initial MTZ concentration was $100 \mathrm{mg} . \mathrm{L}^{-1}$.

\subsubsection{Study of hydroxyl radical generation}

The electrochemical cell was the same as described above. To follow reactive oxygen species and study DMSO, experiments consisted in three steps in absence of metronidazole:

- First step: compressed air was sparged into the 50 mmol.L $\mathrm{L}^{-1}$ sodium sulfate solution during $10 \mathrm{~min}$ at $0.5 \mathrm{~L} \cdot \mathrm{min}^{-1}$ of flow rate in order to saturate the solution with dissolved oxygen.

- Second step: electrodes were polarized at different current densities (Table 1) during 60 min with air sparging in the solution. Hydrogen peroxide production was expected. 
- Third step: DMSO (for a final concentration in solution of $0.25 \mathrm{M})$ and $\mathrm{Fe}^{2+}(0.1 \mathrm{mM})$ were added to the solution, with electrodes polarization and air sparging. Hydroxyl radicals' production was expected and their concentration was followed during $60 \mathrm{~min}$.

Four current intensities 50, 100,300 and $600 \mathrm{~mA}$ were studied and corresponded to the following current densities $0.4,0.9,2.6$ and $5.2 \mathrm{~mA} . \mathrm{cm}^{-2}$ respectively considering a geometrical electrode surface of $115 \pm 1 \mathrm{~cm}^{-2}$. A previous study in the lab [33] showed that considering a three dimensional graphite felt, its electrochemical active surface was around tenfold higher than the geometrical one and hence current densities can be considered ten times lower (Table 1).

\subsection{Analytical procedures}

\subsubsection{High Performance Liquid Chromatography (HPLC).}

The degradation of Metronidazole was measured by HPLC using Waters 996 system equipped with Waters 996 PDA (Photodiode Array Detector) and Waters 600LCD Pump (Waters, Guyancourt, France). The separation was achieved on Waters C $18(5 \mu \mathrm{m} ; 4.6 \times 250 \mathrm{~mm})$ reversed-phase. The eluent consisted of a mixture of acetonitrile/water (20/80, v/v) and $0.1 \%$ formic acid delivered at a flow rate of $1 \mathrm{~mL} \cdot \mathrm{min}^{-1}$. The detection of Metronidazole was carried out at $318 \mathrm{~nm}$ and the retention time was approximately $4.3 \mathrm{~min}$.

\subsubsection{Gas Chromatography (GC) coupled to mass spectrometry (MS).}

DMS chromatograms were carried out using a Clarus 500 chromatograph (Perkin Elmer, Villebon-Sur-Yvette, France) with helium $\left(1 \mathrm{~mL} \cdot \mathrm{min}^{-1}\right)$ as carrier gas, a Varian CP-FFAP-CB column $(25 \mathrm{~m} \times 0.15 \mathrm{~mm} \times 0.25 \mu \mathrm{m})$. The injector was at $300^{\circ} \mathrm{C}$. A temperature gradient in 
the oven was performed: $10^{\circ} \mathrm{C}$ per min from 40 to $120^{\circ} \mathrm{C}$ after 5 min of equilibrium. The detector was a quadrupole mass spectrometer Clarus 500 (Perkin Elmer) with electronic impact as ionization mode.

2.3.2. Total organic carbon (TOC) measurement.

The mineralization of Metronidazole solutions was monitored by the removal of their Total Organic Carbon (TOC). TOC was measured by TOC-V $\mathrm{V}_{\mathrm{CPH} / \mathrm{CPG}}$ Total Organic Analyzer Schimadzu. The catalytic combustion and conversion of organic carbon compounds leads to $\mathrm{CO}_{2}$, which is identified by non-dispersive Infra-Red Detector (NDIR). Calibration was obtained with potassium hydrogen phthalate standards.

\subsubsection{Dissolved oxygen}

Concentration of dissolved oxygen was followed using a potentiometric oxygen probe (DurOx® 325-3, Oxi 3205-set 3, WTW, Weilhen, Germany).

\subsubsection{Hydrogen peroxide quantification}

Hydrogen peroxide concentration was iodometrically measured with thiosulfate as titrant and by amperometric titration with a double Pt indicator electrode and an applied potential difference of $100 \mathrm{mV}$ (Potentio-amperometric TPA4 titrator, Tacussel, Lyon, France).

\subsubsection{Hydroxyl radical quantification}


Hydroxyl radicals were quantified using Dimethyl sulfoxide (DMSO) as trapping agent that is characterized by its high reactivity with ${ }^{\circ} \mathrm{OH}$. DMSO is first oxidized to methanesulfinic acid, that in turn reacts with ${ }^{\circ} \mathrm{OH}$ leading to methanesulfonate. Two radicals ${ }^{\circ} \mathrm{OH}$ are needed to form one molecule of methanesulfonate. Using ion chromatography (DIONEX DX120, Thermo Sicentific, Sunnyvale, USA), methanesulfonate can be detected and quantified allowing the quantification of hydroxyl radicals. Ion chromatograph is provided with a conductivity detector, the stationary phase is constituted by an anion exchange column AS19 (4 x 250 $\mathrm{mm}$ ), and the mobile phase is constituted of $\mathrm{KOH}$ at a concentration of $12 \mathrm{~mol} . \mathrm{L}^{-1} \mathrm{~A}$ gradient elution mode was adopted to accomplish the analyses, $10 \mathrm{mmol} . \mathrm{L}^{-1}$ of $\mathrm{KOH}$ during the first $10 \mathrm{~min}$; then a linear increase up to $45 \mathrm{mM}$ after $25 \mathrm{~min}$; and this latter concentration was maintained from 25 to $35 \mathrm{~min}$. The flow rate was fixed at $1 \mathrm{~mL} \cdot \mathrm{min}^{-1}$ [34].

\section{Results and discussion}

3.1. $\mathrm{H}_{2} \mathrm{O}_{2}$ production and Oxygen behavior

The production of $\mathrm{H}_{2} \mathrm{O}_{2}$ function of electrolysis duration and current density was presented in figure 1. The production of $\mathrm{H}_{2} \mathrm{O}_{2}$ began as soon as the electrodes were polarized (Fig.1) increased up to $30 \mathrm{~min}$ and then remained constant for all the applied current densities showing the implementation of an equilibrium between the cathodic production of $\mathrm{H}_{2} \mathrm{O}_{2}$ (Eq. 2) and its anodic oxidation (Eq. 4).

$\mathrm{H}_{2} \mathrm{O}_{2} \rightarrow \mathrm{O}_{2}+2 \mathrm{e}^{-}+2 \mathrm{H}^{+}$ 
Side reactions that consume hydrogen peroxide can occur such as its electrochemical reduction (Eq. 5) and its dismutation in solution (Eq. 6) [2, 35].

$$
\begin{aligned}
& \mathrm{H}_{2} \mathrm{O}_{2}+2 \mathrm{H}^{+}+2 \mathrm{e}^{-} \quad \rightarrow \quad 2 \mathrm{H}_{2} \mathrm{O} \\
& 2 \mathrm{H}_{2} \mathrm{O}_{2} \rightarrow \quad \mathrm{O}_{2}+2 \mathrm{H}_{2} \mathrm{O}
\end{aligned}
$$

The production of hydrogen peroxide increased up to $0.07 \mathrm{~mA} . \mathrm{cm}^{-2}$ and then decreased with the current intensity (Table 2). Concentration of dissolved oxygen in solution was then followed in order to understand the evolution of hydrogen peroxide concentration with the current density. During the first step, namely 10 min, dissolved oxygen concentration remained constant for all the current densities, around 9 mg.L ${ }^{-1}$ (Fig.2). As soon as the electrodes were polarized, the behavior of the dissolved oxygen concentration depended on the applied current intensity.

For $0.04 \mathrm{~mA} \cdot \mathrm{cm}^{-2}$, the very slight increase of the concentration of dissolved oxygen observed during the second step can be considered as negligible (Fig.2). The $\mathrm{O}_{2}$ feed from compressed air and the in-situ production of $\mathrm{O}_{2}$ from water oxidation (Eq. 7) counteracted its reduction at the cathode to form $\mathrm{H}_{2} \mathrm{O}_{2}$ (Eq.2).

$$
\mathrm{H}_{2} \mathrm{O} \quad \rightarrow \quad 1 / 2 \mathrm{O}_{2}+2 \mathrm{H}^{+} 2 \mathrm{e}^{-}
$$

When the current density increased to $0.07 \mathrm{~mA} \cdot \mathrm{cm}^{-2}, \mathrm{O}_{2}$ concentration decreased in the few first minutes of electrodes polarization (Fig.1) and then remained constant. The oxygen input was insufficient at the beginning of the electrolysis to counteract its electrochemical reduction at the graphite felt surface. At this current density, the production of $\mathrm{H}_{2} \mathrm{O}_{2}$ reached a maximum value of $1.4 \mathrm{mM}$. 
For an applied current density of $0.22 \mathrm{~mA} \cdot \mathrm{cm}^{-2}$, the $\mathrm{O}_{2}$ concentration remained constant even when electrodes were polarized. On the one hand, it can be explained by a lower production of hydrogen peroxide (Fig.2) due to the implementation of the competing 4 electrons reduction of $\mathrm{O}_{2}$ in $\mathrm{H}_{2} \mathrm{O}$ (Eq. 8) and proton reduction (Eq.9). On the other hand, the part of produced $\mathrm{O}_{2}$ at the anode (Eq.7) increased with the current intensity.

$$
\begin{aligned}
& \mathrm{O}_{2}+4 \mathrm{H}^{+} 4 \mathrm{e}^{-} \rightarrow \quad 2 \mathrm{H}_{2} \mathrm{O} \\
& 2 \mathrm{H}_{3} \mathrm{O}^{+}+2 \mathrm{e}^{-} \rightarrow \quad \mathrm{H}_{2}+2 \mathrm{H}_{2} \mathrm{O}
\end{aligned}
$$

A significant increase of $\mathrm{O}_{2}$ concentration was initially observed when the electrodes were polarized at $0.45 \mathrm{~mA} . \mathrm{cm}^{-2}$; the concentration tended to decrease thereafter even if final $\mathrm{O}_{2}$ concentration was higher than before electrodes polarization (15 mg. $\mathrm{L}^{-1}$ after $\left.60 \mathrm{~min}\right)$. The increase was supposed to be mainly due to a high anodic production of oxygen (Eq. 7); while its decrease could be explained by its reduction at the cathode to mainly produce $\mathrm{H}_{2} \mathrm{O}$ (Eq.8). At $0.45 \mathrm{~mA} . \mathrm{cm}^{-2}$, protons reduction was the main reaction at the cathode at the expense of the $\mathrm{H}_{2} \mathrm{O}_{2}$ production. Indeed, the concentration of $\mathrm{H}_{2} \mathrm{O}_{2}$ was the lowest at this current intensity (Table 2).

3.2 Degradation and mineralization of metronidazole

Figure 3 showed that the metronidazole was completely degraded within 15 min except at $0.04 \mathrm{~mA} . \mathrm{cm}^{-2}$. The metronidazole degradation followed a first order kinetic (not shown); it 
appeared at the comparison of the apparent kinetic constants that initial degradation rates were similar for $0.07,0.22$ and $0.45 \mathrm{~mA} . \mathrm{cm}^{-2}$ (Table2).

For current densities from 0.07 to $0.45 \mathrm{~mA} . \mathrm{cm}^{-2}$, mineralization yields were of the same order of magnitude and followed the same evolution than hydrogen peroxide (Table 2); the highest mineralization yield was obtained for galvanostatic electrolysis at $0.07 \mathrm{~mA} . \mathrm{cm}^{-2}$. However, the evolution of the hydroxyl radical concentrations with the mineralization yields and the apparent kinetic constant were not in accordance. For example, at $0.45 \mathrm{~mA} . \mathrm{cm}^{-2}$, the highest concentration of hydroxyl radicals was produced and the lowest mineralization yield was attained. In view of these results, the question on the determination of hydroxyl radicals with DMSO could be raised.

\subsection{Hydroxyl radicals' quantification with DMSO}

From the electro-Fenton mechanism, hydroxyl radicals are produced from the reaction between hydrogen peroxide and ferrous ions (Eq. 1). Side reactions such as dimerisation (Eq. 10), oxidation of ferrous ions (Eq. 11) or reaction with hydrogen peroxide (Eq. 12) can consume a part of produced hydroxyl radicals [2, 35].

$$
\begin{array}{lll}
\cdot \mathrm{OH}+{ }^{\circ} \mathrm{OH} & \rightarrow & \mathrm{H}_{2} \mathrm{O}_{2} \\
\cdot \mathrm{OH}+\mathrm{Fe}^{2+} & \rightarrow & \mathrm{OH}^{-}+\mathrm{Fe}^{3+} \\
\cdot \mathrm{OH}+\mathrm{H}_{2} \mathrm{O}_{2} & \rightarrow & \mathrm{H}_{2} \mathrm{O}+\mathrm{HO}_{2}{ }^{\circ}
\end{array}
$$

As mentioned in the introduction, hydroxyl radicals were quantified using DMSO as probe in the third part of the experiments (performed without MTZ in solution) and production of 
hydroxyl radicals was compared with the production of hydrogen peroxide and MTZ mineralization yield obtained for the applied current densities (Table 2).

The production of hydroxyl radicals during the electrolysis is presented in the figure 4, their concentration increased with the applied current intensity. It was not therefore linked to the amount of hydrogen peroxide produced during the second part of the experiments (Table 2). It could be supposed that electro-oxidation at the highest current intensities was responsible for the formation of hydroxyl radicals at the Pt anode surface. But if electro-oxidation took place besides electro-Fenton during electrolysis at 0.22 and $0.45 \mathrm{~mA} . \mathrm{cm}^{-2}$, mineralization yields should be improved with respect to $0.07 \mathrm{~mA} . \mathrm{cm}^{-2}$ which was not the case here. It can be supposed that for these current densities, the formation of ${ }^{\bullet} \mathrm{OH}$ was mostly due to electrooxidation. In their review, Brillas et al. [2] specified that for Pt anodes, the oxidative action of $\cdot \mathrm{OH}$ adsorbed at the electrode surface is quite low.

Pt is considered as an active electrode, hydroxyl radicals are chemisorbed at the electrode surface and the reactant has to be transferred to the anode surface to react with active oxygen specie (Eq. 13 and 14) [36]. That could explain the low mineralization yields observed at 0.22 and $0.45 \mathrm{~mA} \cdot \mathrm{cm}^{-2}$.

$\begin{array}{lll}\mathrm{MO}_{\mathrm{x}}\left({ }^{\circ} \mathrm{OH}\right) & \rightarrow & \mathrm{MO}_{\mathrm{x}+1}+\mathrm{H}^{+}+\mathrm{e}^{-} \\ \mathrm{MO}_{\mathrm{x}+1}+\mathrm{R} & \rightarrow & \mathrm{MO}_{\mathrm{x}}+\mathrm{RO}\end{array}$

Moreover, the electro-oxidation process can be subdivided into four steps (i) Transfer of reactants to the platinum electrode (ii) Oxidation reaction at the electrode surface (iii) desorption of byproducts (iv) transfer of products to bulk phase. In the case of diluted solutions, the mass transfer (step (i)) remains the limiting step. The high concentration of 
hydroxyl radical concentration obtained (Fig. 4) could be partially explained by mass transfer to the anode surface. Indeed, comparing the operating conditions of DMSO oxidation with those of metronidazole, the main difference is the concentration of the compounds to be oxidized. Indeed the initial MTZ concentration in the experiments was $100 \mathrm{mg} . \mathrm{L}^{-1}$ corresponding to 5,8 $10^{-4} \mathrm{M}$ against $0.25 \mathrm{M}$ for DMSO; the latter cannot therefore be considered as diluted in solution. The probability for DMSO to react at the anode surface is then higher compared to MTZ and could explain obtained hydroxyl radical concentrations.

\subsubsection{Electrochemical behavior of DMSO}

Electrochemical behavior of DMSO was studied in the literature [37, 38]. In acidic media $(0.5$ $\mathrm{M} \mathrm{H}_{2} \mathrm{SO}_{4}$ ), DMSO can be both oxidized and reduced on a Pt electrode. From these studies, dimethylsulfone is the major by-product of DMSO oxidation, also specified by Popović et al.

[39]. From the literature [40], even if the reaction between hydroxyl radicals and dimethylsulfone is slower than with DMSO, it proceeds also via the addition of a hydroxyl radical followed by a methyl radical elimination leading to the formation of methanesulfonate.

DMSO can also be reduced to dimethylsulfide in the hydrogen region; Dimethyl sulfide (DMS) can be in turn oxidized by hydroxyl radicals into DMSO, $\mathrm{SO}_{2}$ and methanesulfonic acid [41]. To verify this assumption, the detection of DMS at different current densities was carried out using GC-MS. Figure 5 shows that DMS was detected at 0.22 and $0.45 \mathrm{~mA} . \mathrm{cm}^{-2}$. However, for $0.07 \mathrm{~mA} . \mathrm{cm}^{-2}$, production of DMS was not detected, confounded with the blank. In this way, methanesulfonate was not produced only via the oxidation of DMSO by hydroxyl radicals but also via the electrochemical oxidation and reduction of DMSO particularly for 0.22 and $0.45 \mathrm{~mA} \cdot \mathrm{cm}^{-2}$. The quantification of the hydroxyl radicals could then be erroneous and could explain the observed results. 


\subsubsection{Evolution of $\mathrm{O}_{2}$ concentration}

For all applied current densities, the decrease of $\mathrm{O}_{2}$ concentration was measured since the addition of DMSO and Fe(II) in the electrochemical cell. The concentration decrease was more important with the increase of the current intensity (Fig.2). Methanesulfonate is a stable intermediate of the reaction between DMSO and ${ }^{\circ} \mathrm{OH}[28,42]$. From the mechanism of Lee et al. [28], oxygen participates to the oxidation of methanesulfinate into methanesulfonate. The consumption of oxygen during the oxidation of DMSO could explain the observed decrease during the electrolysis (Fig.2). A limiting concentration of oxygen could alter the results. For an applied current density of $0.04 \mathrm{~mA} \cdot \mathrm{cm}^{-2}$, the concentration of oxygen did not seem a limiting factor because oxygen remained in solution. However, it was not the case for 0.22 and $0.45 \mathrm{~mA} . \mathrm{cm}^{-2}$, for which the dissolved oxygen was almost totally consumed. For 0.22 and $0.45 \mathrm{~mA} . \mathrm{cm}^{-2}$, the reduction of DMSO into DMS was shown (Fig.5) and DMS reacted with oxygen to produce methanesulfonate. For high current intensities, oxygen is needed for both the oxidation of methanesulfinate and for the oxidation of DMS.

For an applied current density of $0.07 \mathrm{~mA} . \mathrm{cm}^{-2}$, an oxygen limitation can be questioned. For this purpose, a new electrolysis was carried out at this current density with an air flow rate of 3 L.min- ${ }^{1}$ instead of 0.5 L.min- ${ }^{1}$. Figure 6 shows the evolution of the production of hydrogen peroxide and hydroxyl radicals for two different air flow rates, 0.5 and $3 \mathrm{~L} . \mathrm{min}^{-1}$. The concentrations of hydrogen peroxide were similar during the electrolysis considering the uncertainties for the two tested air flow rates (Fig. 6a). The concentration of dissolved oxygen in aqueous phase had a negligible influence on the formation of methanesulfonate and hence on the production of hydroxyl radicals excepted for the last point, $135 \mathrm{~min}$ (Fig. 6b). 


\section{Conclusion}

In this study, DMSO was investigated as hydroxyl radical probe in order to highlight the role of current density on the mineralization, here the MTZ mineralization by the electro-Fenton process. Concentrations of dissolved oxygen and hydrogen peroxide were also followed to explain the obtained results. The concentration of hydrogen peroxide increased with the current density up to $0.07 \mathrm{~mA} \cdot \mathrm{cm}^{-2}$; while the decrease of its production for higher current density was mainly due to the competing reduction of oxygen into water and proton reduction. Concentrations of ${ }^{\circ} \mathrm{OH}$ unlike those of $\mathrm{H}_{2} \mathrm{O}_{2}$, increased with the current density even for the highest ones tested. Consequently, the mineralization yields for MTZ should have increased up to $0.45 \mathrm{~mA} \cdot \mathrm{cm}^{-2}$, but it was not the case. In fact, the quantification of hydroxyl radicals was distorted for the highest current intensities because of the electrochemical oxidation and reduction of DMSO at the electrode surface. The evolution of dissolved oxygen also showed that this compound could be a limiting reagent during the oxidation of methanesulfinate into methanesulfonate. However, it should be noted that for an electro-Fenton process, working at 0.22 and $0.45 \mathrm{~mA} \cdot \mathrm{cm}^{-2}$ is useless because of competing reactions. However, working at these current densities can be interesting to better understand the behavior of DMSO during electrooxidation. In this work, DMSO was found to be efficient for the determination of hydroxyl radical concentration in an electrochemical mono-compartment reactor for current densities up to $0.07 \mathrm{~mA} \cdot \mathrm{cm}^{2}$. In these operating conditions, DMSO could then be useful to determine the optimal production of hydroxyl radical during the treatment of recalcitrant organic compounds. However, because of the electrochemical reactions of DMSO on graphite felt and Pt surface, this compound seems not appropriate as hydroxyl radical probe in electrooxidation. 
The authors are also pleased to express their grateful acknowledgements to F. Bon, English teacher at the University Rennes1 for its help..

The authors want to thank the Lebanese University for the PhD fellowship of Miss Abou Dalle. 


\section{Bibliographic references}

[1] C. Comninellis, A. Kapalka, M. Malato, S.A. Parsons, I. Poulios, D. Mantzavinos, Advanced oxidation processes for water treatment: advances and trends for R\&D, J. Chem. Technol. Biotechnol., 83 (2008) 769-776.

[2] E. Brillas, I. Sirés, M.A. Oturan, Electro-Fenton process and related electrochemical technologies based on Fenton's reaction chemistry, Chem. Rev., 109 (2009) 6570-6631.

[3] I. Sirés, E. Brillas, Remediation of water pollution caused by pharmaceutical residues based on electrochemical separation and degradation technologies. A review., Environ. Int., 102 (2012) 212-229.

[4] F.C. Moreira, R.A.R. Boaventura, E. Brillas, V.J.P. Vilar, Electrochemical advanced oxidation processes - A review on thier application to synthetic and real wastewater., Appl. Catal. B, 202 (2017) 217-261.

[5] L. Heng, Z. Hui, Treatment of organic pollutants using electro-Fenton and electro-Fenton like process in aqueous solution., Prog. Chem., 27 (2015) 1123-1132.

[6] P.V. Nidheesh, R. Gandhimathi, S.T. Ramesh, Degradation of dyes from aqueous solution by Fenton processes: a review., Environ. Sci. Pollut. Res., 20 (2013) 2099-2132.

[7] F. Fourcade, M. Delawarde, L. Guihard, S. Nicolas, A. Amrane, Electrochemical reduction prior to electro-Fenton oxidation of azo dyes: Impact of the pretreatment on biodegradability., Water Air Soil Poll., 224 (2013) 1-11.

[8] J.M. Fontmorin, R.C. Burgos Castillo, W. Tang, M. Sillanpää, Stability of 5,5-dimethyl-1pyrroline-N-oxide as a spin-trap for quantification of hydroxyl radicals in processes based on Fenton reaction., Water Res., 99 (2016) 24-32.

[9] C.J. Miller, A.L. Rose, T.D. Waite, Phthalhydrazide chemiluminescence methode for determination of hydroxyl radical production: Modifications and adaptations for use in natural systems., Anal. Chem., 83 (2011) 261-268.

[10] S. Qiu, D. He, J. Ma, T. Liu, T.D. Waite, Kinetic modeling of the electro-Fenton process: quantification of reactive oxygen species generation., Electrochim. Acta, 176 (2015) 51-58.

[11] T. Maezono, M. Tokumura, M. Sekine, Y. Kawase, Hydroxy radical concentration profile in photo-Fenton oxidation process: generation and consumption of hydroxyl radicals during discoloration of Orange II., Chemosphere, 82 (2011) 1422-1430.

[12] Z.R. Lin, L. Zhao, Y.H. Dong, Quantitative characterization of hydroxyl radical generation in a goethite-catalyzed Fenton-like reaction., Chemosphere, 141 (2015) 7-12.

[13] R. Romero, D. Contreras, C. Segura, B. Schwederski, W. Kaim, hydroxyl radical production by a heterogeneous Fenton reaction supported in insoluble tannin from bark of Pinus radiata., Environ. Sci. Pollut. Res., ahead of print. DOI 10.1007/s11356-016-7532-1 (2016). 
[14] C.H. Tung, J.H. Chang, Y.H. UHsieh, J.C. Hsu, A.V. Ellis, W.C. Liu, R.H. Yan, Comparison of hydroxyl radical yields between photo- and electro-catalyzed water treatments., J. Taiwan Inst. Chem. E. , 45 (2014) 1649-1654.

[15] I.A. Katsoyiannis, S. Canonica, U. Von Guten, Efficiency and energy requirements for the transformation of organic micropollutants by ozone, $\mathrm{O} 3 / \mathrm{H} 2 \mathrm{O} 2$ and $\mathrm{UV} / \mathrm{H} 2 \mathrm{O} 2$., Water Res., 45 (2011) 3811-3822.

[16] E. Peralta, G. Roa, J.A. Hernandez-Servin, R. Romero, P. Balderas, R. Natividad, Hydroxyl radicals quantification by UV spectrophotometry., Electrochim. Acta, 129 (2014) 137-141.

[17] J.F. Jen, M.F. Leu, T.C. Yang, Determination of hydroxyl radicals in an advanced oxidation process with salicylic acid trapping and liquid chromatography., J. Chromatogr. A, 796 (1998) 283-288.

[18] J.L. Acero, K. Stemmler, U. Von Guten, Degradation kinetics of atrazine and its degradation products with ozone and $\mathrm{OH}$ radicals: a predictive tool for drinking water treatment., Environ. Sci. Technol., 34 (2000) 591-597.

[19] J. Yang, J. Li, W. Dong, J. Ma, T. Li, Y. Yang, J. Li, J. Gu, Deethylatrazine as a more appropriate hydroxyl radical probe compound during ozonation: Comparison with the widely used $\rho$-chlorobenzoic acid., Chem. Eng. J., 295 (2016) 443-450.

[20] J. Muff, L.R. Bennedsen, E.G. Søgaard, Study of electrochemical bleaching of $\rho$ nitrosodimethylaniline and its role as hydroxyl radical probe compound., J. Appl. Electrochem., 41 (2011) 599-607.

[21] N. Belhadj Tahar, R. Abdellhédi, A. Savall, Electrochemical polymerisation of phenol in aqueous solution on a Ta/PbO 2 anode., J. Appl. Electrochem., 39 (2009) 663-669.

[22] S.S. Medany, K.M. Ismail, W.A. Badawy, Kinetic of the electropolymerisation of aminoanthraquinone from aqueous solutions and analytical applications of the polymer film., J.A.R., 3 (2012) 261-258.

[23] M.A. Rodrigo, P.A. Michaud, I. Duo, M. Panizza, G. Cerisola, C. Comminelis, Oxidation of 4-chlorophenol at boron-doped diamond electrode for wastewater treatment., J.

Electrochem. Soc., 148 (2001) D60-D64.

[24] M.A. Oturan, N. Oturan, C. Lahitte, S. Trevin, Production of hydroxyl radicals by electrochemically assisted Fenton's reagent: application to the mineralization of an organic micropollutant, pentachlorophenol., J. Electroanal. Chem., 507 (2001) 96-102.

[25] L. Codognoto, S.A.S. Machado, L.A. Avaca, Selective oxidation of pentachlorophenol on diamond electrodes., J. Appl. Electrochem., 33 (2003) 951-957.

[26] H. Lund, O. Hammerich, Organic electrochemistry, Four edition, Marcel Decker, INC, New York, 2001. 
[27] M.G. Steiner, C.F. Babbs, Quantitation of the hydroxyl radical by reaction with dimethylsulfoxide., Arch. Biochem. Biophys., 278 (1990) 478-481.

[28] Y. Lee, C. Lee, J. Yoon, Kinetics and mechanism of DMSO (dimethylsulfoxide) degradation by $\mathrm{UV} / \mathrm{H}_{2} \mathrm{O}_{2}$ process., Water Res., 38 (2004) 2579-2588.

[29] M.D.G. De Luna, J.I. Colades, C.C. Su, M.C. Lu, Comparison of dimethylsulfoxide degradation by different Fenton processes., Chem. Eng. J., 232 (2013) 418-424.

[30] T. Pérez, S. Garcia-Segura, A. El-Ghenymy, J.L. Nava, E. Brillas, Solar photoelectroFenton degradation of the antibiotic metronidazole using a flow plant with a Pt/air-diffusion cell and a CPC photoreactor., Electrochim. Acta, 165 (2015) 173-181.

[31] H. Shemer, Y.K. Kunukcu, K.G. Linden, Degradation of the pharmaceutical metronidazole via UV Fenton and photo-Fenton processes., Chemosphere, 63 (2006) 293276.

[32] W. Cheng, M. Yang, Y. Xie, B. Liang, Z. Fang, E.P. Tsang, Enhancement of mineralization of metronidazole by the electro-Fenton process with a $\mathrm{Ce} / \mathrm{SnO}_{2}-\mathrm{Sb}$ coated titanium anode., Chem. Eng. J., 220 (2013) 214-220.

[33] J.M. Fontmorin, F. Fourcade, F. Geneste, I. Soutrel, D. Floner, A. Amrane, Direct electrochemical oxidation of a pesticide, 2,4-dichlorophenoxyacetic acid, at the surface of a graphite felt electrode: biodegradability improvement., C.R. Chimie, 18 (2015) 32-38.

[34] S. Yahiat, F. Fourcade, S. Brosillon, A. Amrane, Removal of antibiotics by integrated process coupling photocatalysis and biological treatment - Case of tetracycline and tylosin., Int. Biodeter. Biodegr., 65 (2011) 997-1003.

[35] T. Tzédakis, A. Savall, M.J. Clifton, The electrochemical regeneration of Fenton's reagent in the hydroxylation of aromatic substrates: batch and continuous processes., J. Appl.

Electrochem., 19 (1989) 911-921.

[36] M. Panizza, G. Cerisola, Direct and mediated anodic oxidation of organic pollutants., Chem. Rev., 109 (2009) 6541-6569.

[37] S. Wasmus, W. Vielstich, Electro-oxidation and reduction of Dimethylsulfoxide and Sulfolane in aqueous acid solution - An on-line MS study., Electrochim. Acta, 38 (1993) 175183.

[38] J. Sobkowski, M. Szklarczyk, The behaviour of high polar organic solvents on platinium electrodes- I. The study of adsorption and electrode reactions of dimethylsulfoxide., Electrochim. Acta, 25 (1980) 383-389.

[39] N.D. Popović, D.C. Johnson, A ring-disk study of the competition between anodic oxygen-transfer and dioxygen evolution reactions., Anal. Chem., 70 (1998) 468-472.

[40] I. Barnes, J. Hjorth, N. Mihalopoulos, Dimethyl sulfide and dimethyl dulfoxide and their oxidation in the atmosphere., Chem. Rev., 106 (2006) 940-975. 
[41] C. Arsene, I. Barnes, K.H. Becker, FT-IR product study of the photo-oxidation of dimethyl sulfide: Temperature and $\mathrm{O}_{2}$ partial pressure dependence., Phys. Chem. Chem. Phys., 1 (1999) 5463-5470.

[42] H. Bardouki, M. Barcellos de Rosa, N. Mihalopoulos, W.U. Palm, C. Zetzsch, Kinetic and mechanism of the oxidation of dimethylsulfoxide (DMSO) and methanesulfinate (MSI') by $\mathrm{OH}$ radicals in aqueous media., Atmos. Environ., 36 (2002) 4627-4634. 


\section{Figure Legends}

Fig.1: Hydrogen peroxide concentration evolution during the second step of the experiments in $250 \mathrm{~cm}^{3} \mathrm{Na}_{2} \mathrm{SO}_{4} 0.05 \mathrm{M}$ and $\mathrm{FeSO}_{4} 0.1 \mathrm{mM}$ with graphite felt cathode $\left(42 \mathrm{~cm}^{3}\right)$ and $\mathrm{Pt}$ anode $\left(31.2 \mathrm{~cm}^{2}\right)$. Compressed air sparging: $0.5 \mathrm{~L} \cdot \mathrm{min}^{-1}$.

Fig.2: Evolution of dissolved oxygen concentration during the three steps of the experiments $\left(\left[\mathrm{O}_{2}\right]_{0}=9 \mathrm{mg} \cdot \mathrm{L}^{-1}\right)$.

Fig.3: Evolution of MTZ concentrations (initial concentration of $100 \mathrm{mg} . \mathrm{L}^{-1}$ ) during electrolysis in $250 \mathrm{~cm}^{3} \mathrm{Na}_{2} \mathrm{SO}_{4} 0.05 \mathrm{M}$ and $\mathrm{FeSO}_{4} 0.1 \mathrm{mM}$ with graphite felt cathode $\left(42 \mathrm{~cm}^{3}\right)$ and Pt anode $\left(31.2 \mathrm{~cm}^{2}\right)$. Compressed air sparging: 0.5 L. $\mathrm{min}^{-1}$.

Fig.4: Evolution of accumulated ${ }^{\circ} \mathrm{OH}$ concentration function of current density during electrolysis in $250 \mathrm{~cm}^{3} \mathrm{Na}_{2} \mathrm{SO}_{4}$ 0.05M, DMSO $0.25 \mathrm{M}, \mathrm{FeSO}_{4} 0.1 \mathrm{mM}$ with graphite felt cathode $\left(42 \mathrm{~cm}^{3}\right)$ and Pt anode $\left(31.2 \mathrm{~cm}^{2}\right)$. Compressed air sparging: $0.5 \mathrm{~L} \cdot \mathrm{min}^{-1}$.

Fig.5: GC-MS Chromatograms of volatile DMS for different current densities: blank (0 mA.cm ${ }^{-2}$ ), 0.07, 0.22 and $0.45 \mathrm{~mA} . \mathrm{cm}^{-2}$. Experiments carried out in $250 \mathrm{~cm}^{3} \mathrm{Na}_{2} \mathrm{SO}_{4} 0.05 \mathrm{M}$, DMSO 0.25 M and $\mathrm{FeSO}_{4} 0.1 \mathrm{mM}$ with graphite felt cathode $(42 \mathrm{~cm} 3)$ and $\mathrm{Pt}$ anode $(31.2$ $\mathrm{cm}^{2}$ ). Compressed air sparging: 0.5 L. $\mathrm{min}^{-1}$.

Fig.6: Evolution of hydrogen peroxide concentration during the second step of the experiments (a) and evolution of hydroxyl radical concentration (b) during the third part of experiments at $0.07 \mathrm{~mA} . \mathrm{cm}^{-2}$ in $250 \mathrm{~cm}^{3} \mathrm{Na}_{2} \mathrm{SO}_{4}$ 0.05M, DMSO 0.25 M and FeSO4 $0.1 \mathrm{mM}$. 


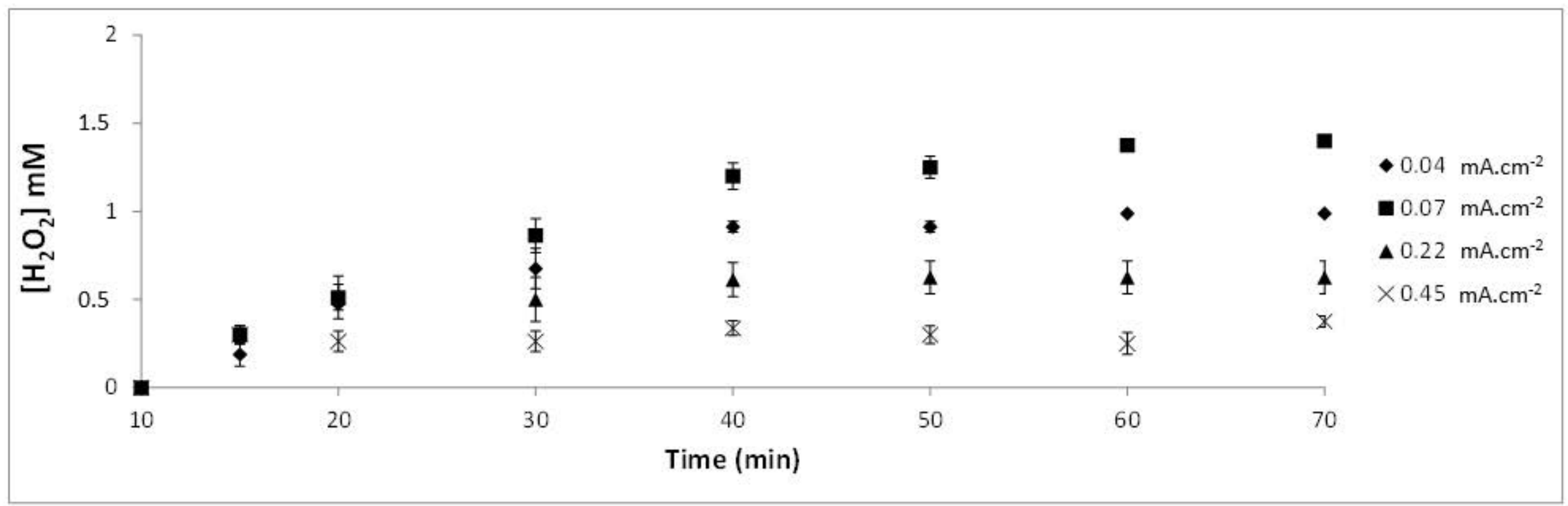




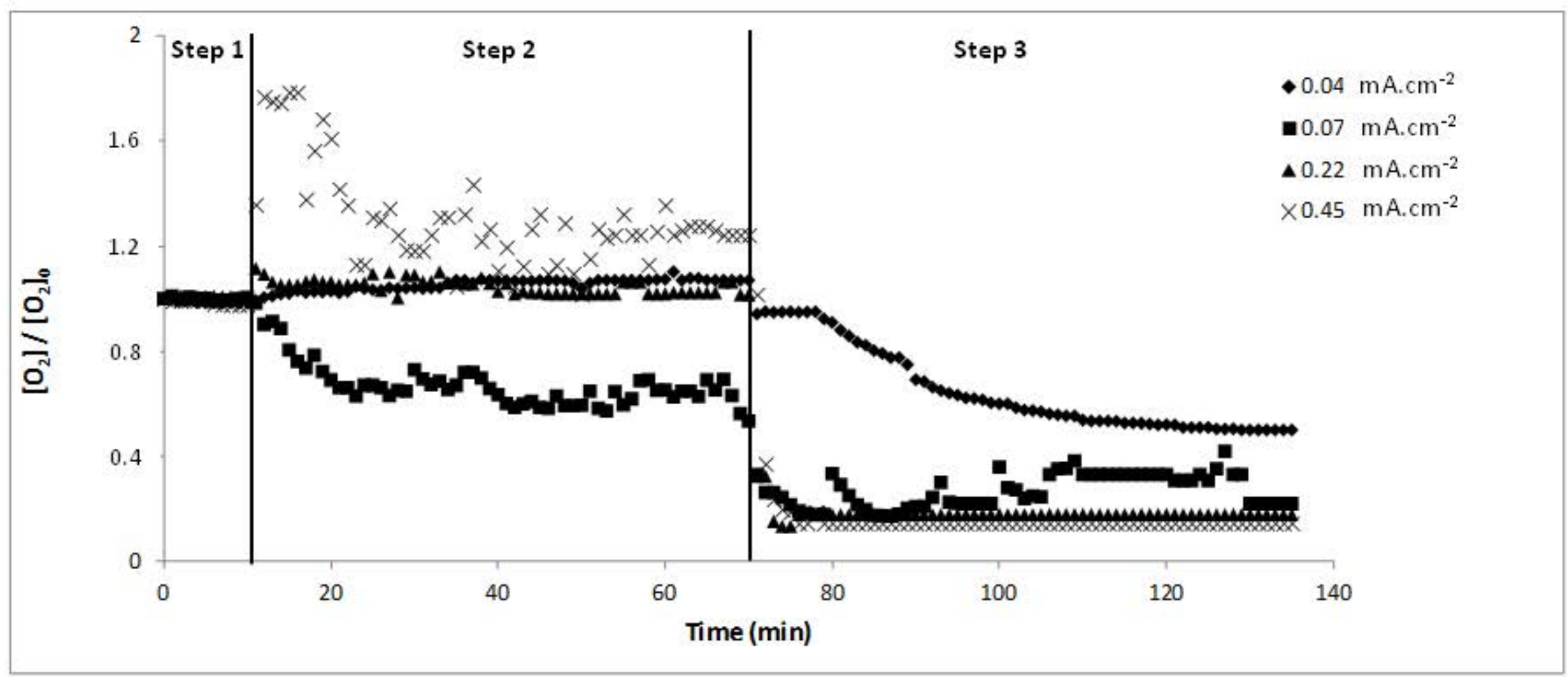




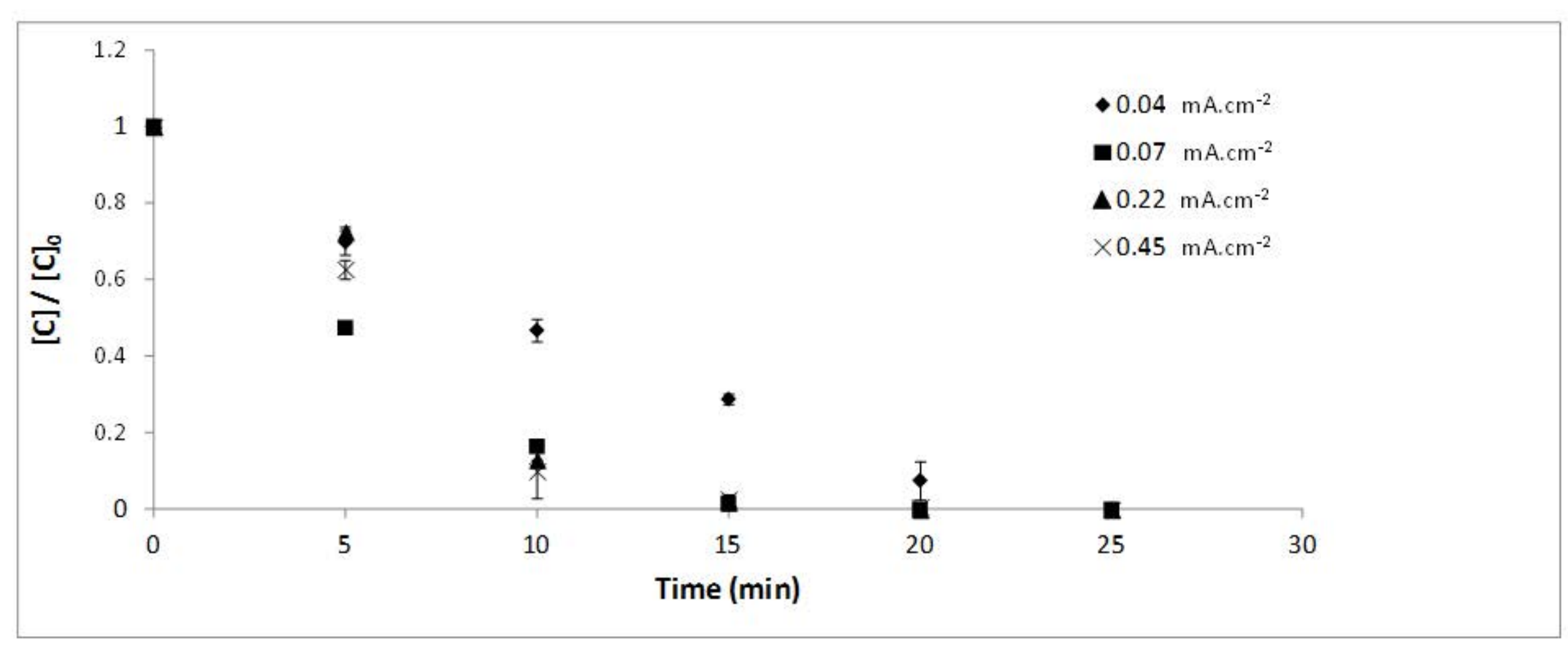




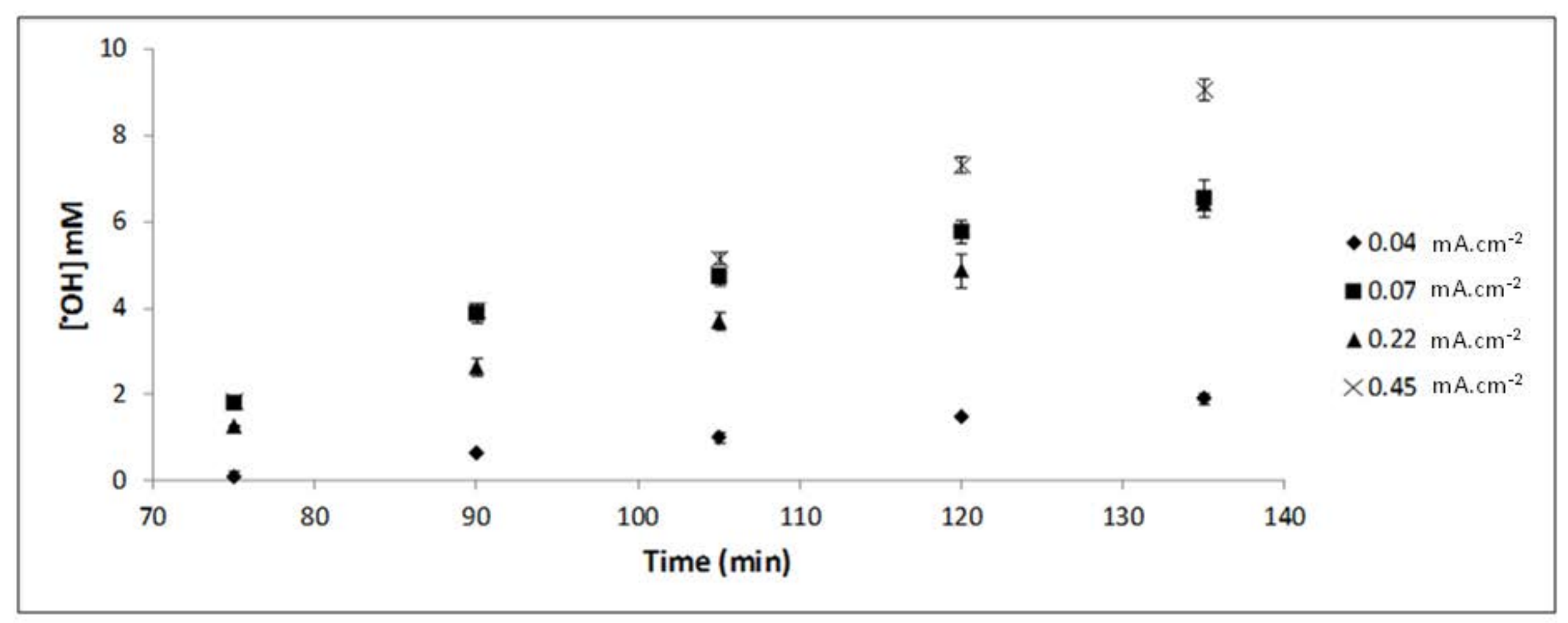




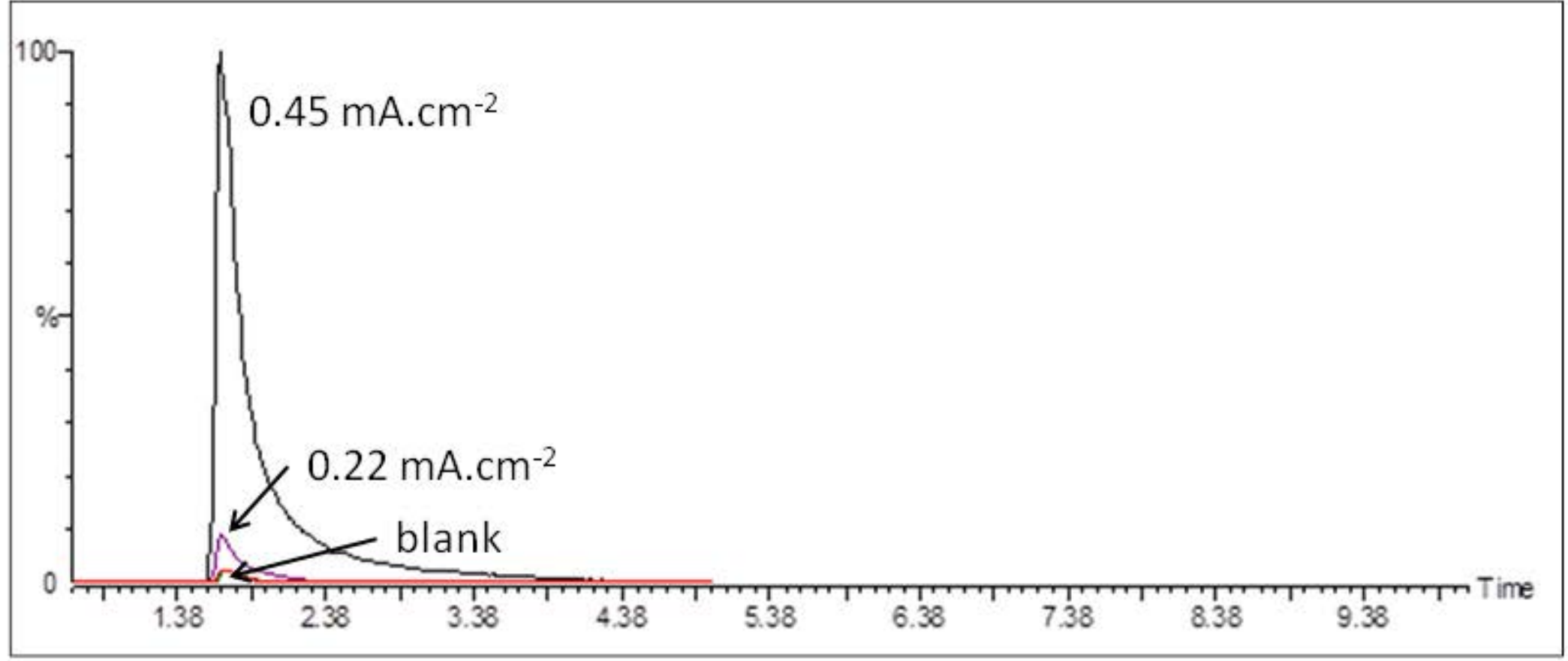




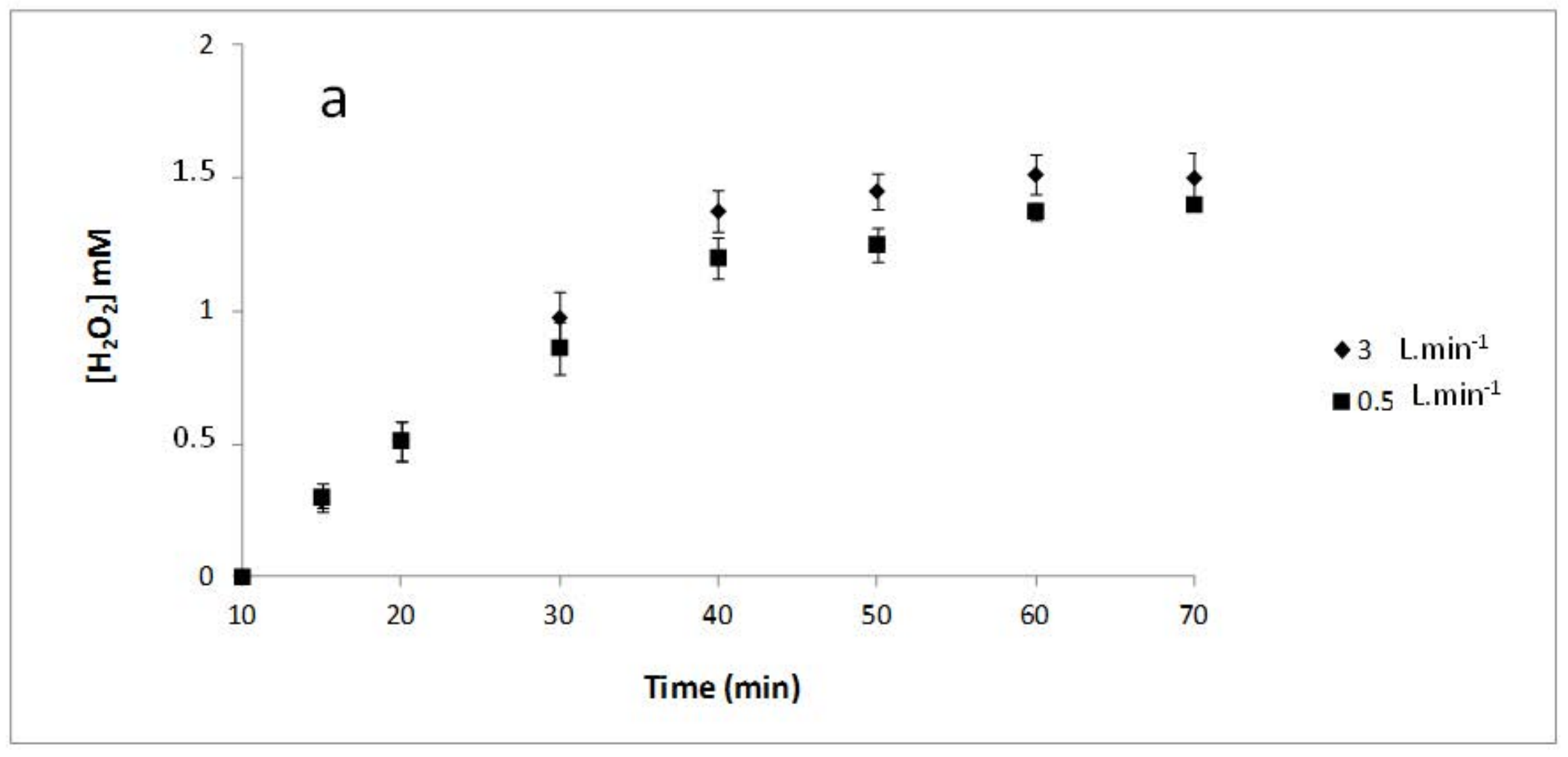




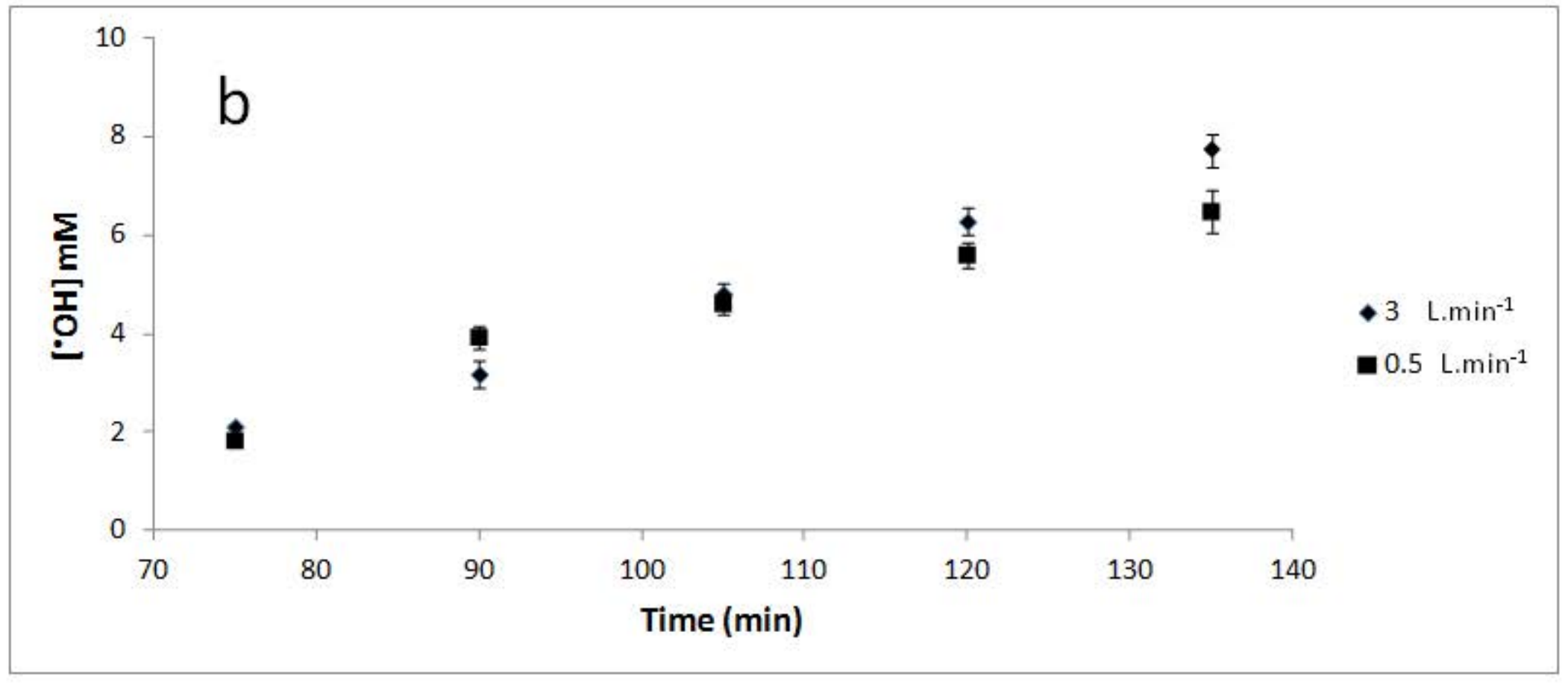


Table 1: Current densities values

\begin{tabular}{lll}
\hline Current intensity $(\mathrm{mA})$ & Current density $\left(\mathrm{mA} . \mathrm{cm}^{-2}\right)$ & Current density $\left(\mathrm{mA} . \mathrm{cm}^{-2}\right)$ \\
& Geometrical surface & Electrochemical surface \\
\hline 50 & $0.43 \pm 0.01$ & $0.04 \pm 0.01$ \\
100 & $0.87 \pm 0.01$ & $0.07 \pm 0.01$ \\
300 & $2.61 \pm 0.02$ & $0.22 \pm 0.02$ \\
600 & $5.22 \pm 0.05$ & $0.45 \pm 0.04$ \\
\hline
\end{tabular}

Table 2: Concentrations of actives species (accumulated values of $\mathrm{H}_{2} \mathrm{O}_{2}$ and ${ }^{\circ} \mathrm{OH}$ ), apparent kinetic constants and mineralization yields at after 60 min of electrolysis (end of $2^{\text {nd }}$ step) and at the end of experiment (end of the 3th step)

\begin{tabular}{lllll}
\hline $\begin{array}{l}\text { Current density } \\
\left(\mathrm{mA} . \mathrm{cm}^{-2}\right)\end{array}$ & $\mathrm{k}\left(\mathrm{min}^{-1}\right)$ & Mineralization yield & $\begin{array}{l}{\left[\mathrm{H}_{2} \mathrm{O}_{2}\right]} \\
(\mathrm{mM})\end{array}$ & $\begin{array}{l}{\left[{ }^{\circ} \mathrm{OH}\right]} \\
(\mathrm{mM})\end{array}$ \\
\hline 0.04 & 0.08 & $26.00 \pm 0.04$ & $0.99 \pm 0.01$ & $1.91 \pm 0.14$ \\
0.07 & 0.238 & $40.1 \pm 2.7$ & $1.40 \pm 0.01$ & $6.50 \pm 0.12$ \\
0.22 & 0.232 & $28.5 \pm 4.8$ & $0.62 \pm 0.02$ & $6.42 \pm 0.08$ \\
0.45 & 0.226 & $17.8 \pm 3.9$ & $0.37 \pm 0.02$ & $9.07 \pm 0.24$ \\
\hline
\end{tabular}

